\title{
ウインドミル投法の筋電図的分析
}

一競技レベルによる相逵とボール速度の変化を中心にしてー

$$
\text { 奥 野 暢 通 }{ }^{1)} \text { 後藤 幸 } \text { 弘 }^{21} \text { 島 田三千男 }{ }^{31}
$$

\section{Electromyographical analysis of the windmill pitch: Influence of the skill level and ball velocity}

\author{
Masamichi Okuno ${ }^{1}$, Yukihiro Goto ${ }^{2}$ and Michio Shimada ${ }^{3}$
}

\begin{abstract}
Two groups consisting of five and three adult males, who are skilled and unskilled in the windmill pitch, respectively, were selected as the subjects, and the electromyographic difference in the pitching originated in the skill level and ball velocity was studied using of EMG's and VTR's.

1) Between the initial velocity of ball $(\mathrm{Y})$ and maximum angular velocity $(\mathrm{X})$ of the angle between horizontal and the line connecting shoulder and wrist, the relationships found for the skilled subjects were $y=0.020 x-1.28(r=.913, p<.001)$ and the unskilled $y=0.015 x+0.73$ $(r=.867, p<.01)$, respectively.

2) The unskilled had no significant correlation between the horizontal maximum velocity of the wrist and maximum angular velocity of the angle between the forearm and brachium, and this finding suggests that they can not use their elbow joint for pitching.

3) Between the initial velocity of the ball and horizontal maximum velocity of the wrist just before releasing the ball, a significant correlation was found for both the skilled ( $r=.634$, $\mathrm{p}<.05)$ and the unskilled $(\mathrm{r}=.754, \mathrm{p}<.05)$.

4) Between the initial velocity of the ball and snap ratio, a significant correlation was seen for both these groups, skilled $(r=.852, p<.001)$ and unskilled $(r=.759, p<.05)$, and had comparable regression coefficients.

5) The skilled subjects' pitching consisted of some motion characteristics; a great step length, trunk twisting in the throwing direction, adduction of the shoulder joint, extension and pronation of the elbow joint, and flexion of the wrist joint, while the unskilled showed a small step length, flexion of shoulder joint with a touch of abduction, and the flexion of the wrist joint.

6) The pitching, especially the velocity of ball, was dependent on the skill level even among the skilled subjects. This fact appeared to result from the magnitude of the rotation speed of the upperlimb, the transfer of kinetic energy to the ball via applying the upper portion of forearm on the trunk at the end of forward swing phase, efficiency of the snap motion, and the translational velocity of the center of body's gravity.

7) It was thought that among the skilled, the ball velocity was controlled by the rotation speed of the upperlimb and the strength of the trunk twist. In comparison, the unskilled controlled the velocity by delaying the timing for increasing the rotation speed of the upperlimb and the change in the strength of the backward kick.
\end{abstract}

1）四天王寺国際仏教大学 二583 大阪府羽曳野市学園前

2) 兵庫教育大学 干673-14 兵庫県加東郡社町

3) 西大学 干565 大阪府吹男市千里山東
1. Shitennouji International Buddhist University, Gakuenmae, Habikinocity, Osaka, Japan (583)

2. Hyogo University of Teacher Education, Yashiro-cho, Kato-gun, Hyogo, Japan (673-14)

3. Kwansai University, Senriyama-higashi, Suita-city, Osaka, Japan (565) 
8) The unskilled subjects had poor ability for exhibiting stable performance, which was caused by the rotation speed of the shoulder joint and uncertain snap motion fluctuated ballreleasing point.

Key words: windmill pitch, electromyogram, skill level, ball velocity (Japan J. Phys. Educ., 36: 141-155, September, 1991.)

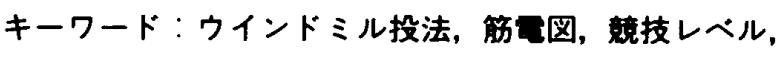
ポール速度

\section{I. 目的}

野球やソフトボールに括いては，投手の能力 の高いことが相手の得点を少なくするための最 も重要な要因と考えられる。

ピッチング能力が高いことには，速いボール が投げられること，多くの球種のボールが投げ られること,制球力のあること等があげられる. 中でも，速いボールが投げられることは，ボー ルに対する打者の反応時間を短くし7，振り遅 れを生じさせたり，ボール速度に大きな変化を つけることでタイミングを狂わせたりすること ができ，打者の能力発揮を抑える重要な能力で あると考えられる。

これまでにも投動作については，平野4や桜 井ほか10)のレビューにみられるように種々の立 場から検討されている。しかし、ソフトボール におけるピッチング動作について筋電図を用い た研究はみられる ${ }^{1,12,13)}$ が筋の作用機序につい ては充分に明らかにされていないよ5に思われ る.

$$
\text { ところで, ソフトボールのピッチングにはウ }
$$
インドミル，スリング，フィギュアーエイト等 の様式があり, 中でもウインドミル投法はボー ルに力を加える作用距離が長く，高いボール速 度を得るために有利な投法であると考えられ る.

そこで，本研究ではウインドミル投法をとり あげ，競技レベルの異なる被験者を対象に筋電 図を記録し，ボール速度を指標に技術段階によ る差異やボール速度を变化させる要因を明らか にしょうとした。すなわち，関西学生 1 部リー クに所属し技術段階の高いと考えられる投手か らウインドミル投法を本格的に練習したことの
ない学生を対象に, 種々の速度のボールを投げ させ，その際の動作をビデオカメラと管電図を 用いて記録し，ボール速度と競技レベルによる 差異を検討した。

これらの知見は，今後ウインドミル投法の指 導法を考える上で基礎的知見を提供するものと 考えられる。

$$
\text { II. 方 法 }
$$

\section{1. 被毭者}

熟練者として関西学生リーグに所属しウイン ドミル投法を専門とする男子投手 5 名（1 部 リーグ：1名，2 部リーグ：4名),ならびに末 熟練者としてウインドミル投法を本格的に練習 したことのない男子学生 3 名を対象にウインド ミル投法で 15一30 球の投球を行わせた。なお， 分析は被験者毎にストライクであった試技の中 からボール速度の異なる 3 試技（最もボール速 度の高かった試技を含む）について行った。

Table 1 に被験者の身体特性や本実験におい て発揮した最高ボール速度をまとめて示した。

\section{2. 功作の梩錄}

\section{（1）映像の記錄と分析}

ビデオカメラ(National 社製, AG-300：60 f/

Table 1. Physical characteristics of the sub-

\begin{tabular}{|c|c|c|c|c|c|}
\hline \multicolumn{2}{|c|}{ subjects } & $\begin{array}{l}\text { height } \\
(\mathrm{cm})\end{array}$ & $\underset{(\mathbf{k g})}{\text { weight }}$ & $\begin{array}{c}\text { career } \\
\text { (years) }\end{array}$ & $\underset{\text { velocitv }(\mathrm{m} / \mathrm{s})}{\operatorname{maximum}}$ \\
\hline \multirow{5}{*}{ 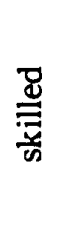 } & K. O. & 173 & 72 & 7 & 28.0 \\
\hline & A. T. & 181 & 78 & 6 & 24.8 \\
\hline & A. $K$. & 175 & 70 & 7 & 24.5 \\
\hline & A. N. & 175 & 60 & 6 & 23.4 \\
\hline & U.S. & 170 & 62 & 5 & 22.0 \\
\hline \multirow{3}{*}{$\frac{\bar{d}}{\frac{\vec{d}}{\overline{7}}}$} & O. H. & 160 & 46 & 0 & 16.9 \\
\hline & A. H. & 154 & 40 & 0 & 15.8 \\
\hline & S.U. & 164 & 60 & 0 & 14.4 \\
\hline
\end{tabular}
jects and their maximum ball velocity 

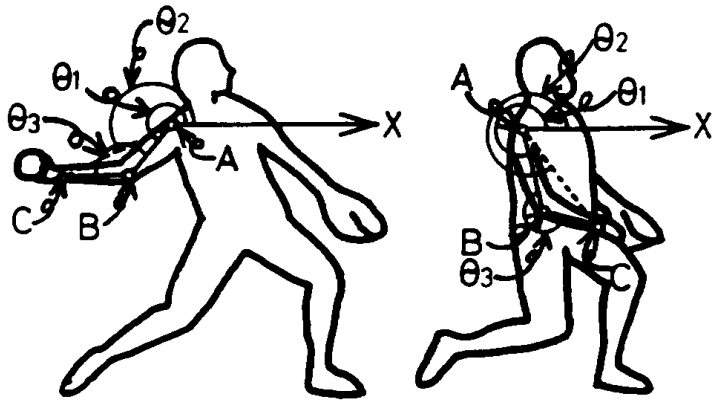

A : Acromion

B : E picondylus aedialis humerus

$C$ : Processus styloideus ulna

$\theta_{1}$ : Angle of upperarn ( $\angle \mathrm{XAB}$ )

$\theta_{2}$ : Angle of upperlinb ( $\angle \mathrm{XAC}$ )

$\theta_{3}$ : Angle of upperar -forearm ( $\angle \mathrm{ABC}$ )

Fig. 1. Schematic illustration for body angle

s）を用い右側方から投球動作を撮影し，投げ腕 側の肩峰突起, 上腕骨尺側上顆, 尺骨茥状突起, ならびにボールの座標位置をグラフペンシステ ム（Nac 社製，Sportias Model-200）を用いて 計測・分析した。すなわち，Fig. 1 に示すよう に，投球方向垂直面で，局峰突起と上腕骨尺側 上顆を結ぶ線が水平線となす角度 $\left(\theta_{1}\right)$, 肩峰突 起と尺骨茥状突起を結ぶ線が水平線となす角度 $\left(\theta_{2}\right)$ ，ならびに上腕と前腕のなす角度 $\left(\theta_{3}\right)$ を反 時計方向で $1 / 60 \mathrm{~s}$ 毎に求め, それぞれについて 角速度 $\left(\dot{\theta}_{1}, \dot{\theta}_{2}, \dot{\theta}_{3}\right)$ を算出した。さらに,リリー ス直後のボールの水平速度とリリース直前の手

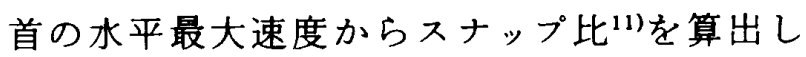
た。なお，投球中の上肢は三次元の動きをする が，投球方向垂直面内の動作がボールに力を加 えるのに主として関与すると考えられるので， 若干の問題はあるが側方のみから撮影し，二次 元の動きについて分析した。

\section{（2）筋電図の記録}

筋電図は, 直径 $10 \mathrm{~mm}$ の円盤電極を使用し 双極皮庙表面誘導法により，18 極多用途脳波計 （三栄測機社製，1 A-59 型，感度：6 mm/0.5 $\mathrm{mv}$, 時定数 : $0.003 \mathrm{~s}$, 紙送り速度 $: 6 \mathrm{~cm} / \mathrm{s}$ )を 用いて記録した。被験筋は，これまでに行われ

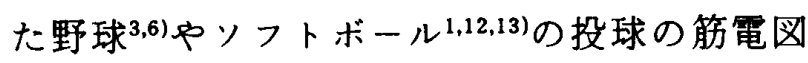
を用いた研究や上肢の基本動作の筋電図的研 究8,9)を参考に，下記の投げ腕側の上肢・上肢帯

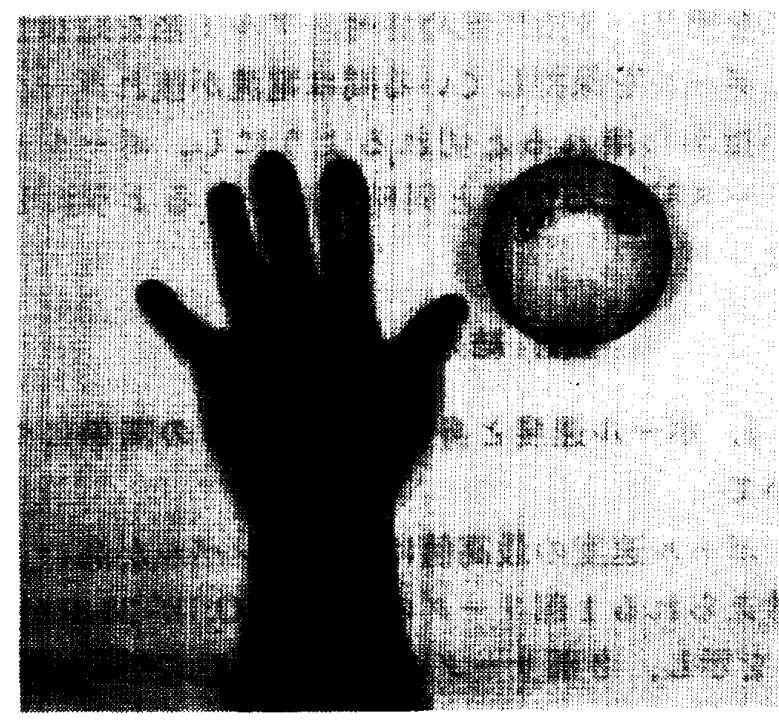

Phot. 1. Contact switch

筋，ならびに下肢筋を選択した。

1）橈側手根伸筋

2）橈側手根屈筋

3）上腕三頭筋 長頭

4）上腕三頭筋 外側頭

5）上腕二頭筋 長頭

6）三角筋 前部

7）三角筋 後部

8）大胸筋 鎖骨部

9）大胸筋 腹部

10）大円筋

11）腓腹筋

さらに，熟練者については下記の筋について も記録した。

12）棘下筋

13）大腿直筋

14）大䊐二頭筋 長頭

15）外腹斜筋（右側）

16）外腹斜笳 (左側)

なお，筋電図とフォームを対応させるために， 同期パルス発生装置 (FOR. A 社製)を用い, ビデオカメラのコマシグナルを筋電図と同時記 録した。

\section{（3）ボールの接指状態の記録}

Phot. 1 に示すように, 事務用指サックに銅線 を貼布したコンタクトスイッチを作成した。こ 
れを第 $2 ， 3$ 指に嵌めさせ，アルミ箔を貼布し たボールを保持している間は電流が流れボール が指から離れると切れるよらにし，ボールリ リース時を筋電図と同時記録できるようにし た.

\section{III. 結果ならぴに考菉}

\section{1. ボール速度と身体各部の功きの䦦係につ} いて

ボール速度の最高値は，競技レベルが高いと 考えられる 1 部リーグの投手(K.O.)が $28.0 \mathrm{~m} /$ $\mathrm{s}$ を示し，2 部リーグの投手 $(24.8-22.0 \mathrm{~m} / \mathrm{s})$ や未熟練者（16.9-14.4 m/s）よりも高かった (Table 1).すなわち，ボール速度は競技レベル と対応することが認められた。山本ほか ${ }^{12)}$ は大 学選手権優勝チームの投手 2 名が全力投球した 際の平均ボール速度は $26.4 \mathrm{~m} / \mathrm{s}$ であったこと を報告している。本研究の K.O. が全力で投球 した際の平均ボール速度は $27.0 \mathrm{~m} / \mathrm{s}$ を示した ことから, 本被験者は大学のトップクラスに位 置する投手であるといえる。

Fig. 2 は，ボールの初速度 (y) と肩を中心と

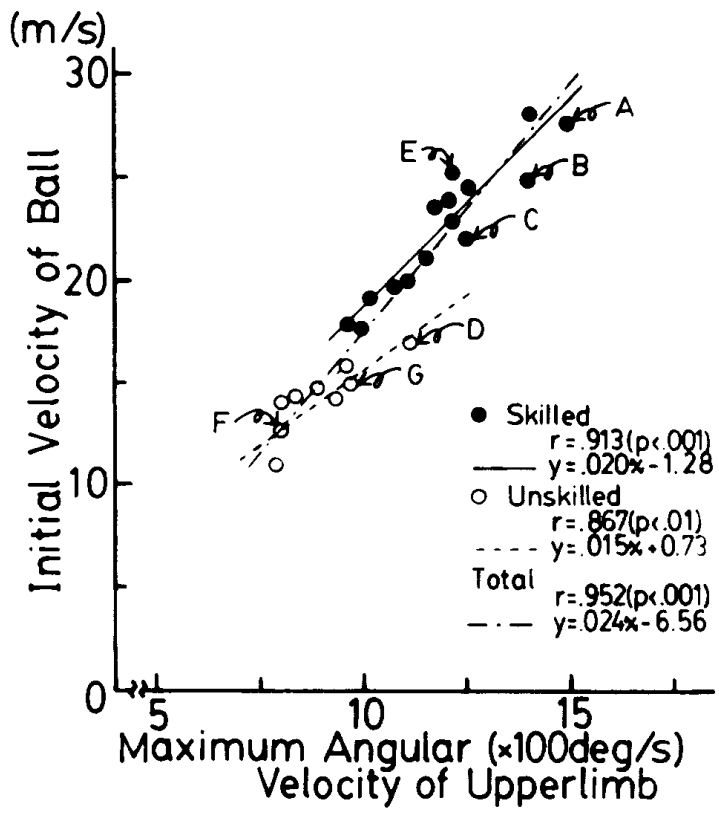

Fig. 2. The relationship between the initial velocity of ball $(y)$ and maximum angular velocity of upperlimb about the shoulder joint $(\mathbf{x})$.
した上肢の角速度 $\left(\dot{\theta}_{2}\right)$ の最大値 $(\mathbf{x})$ の関係を 示したものである.なお，Fig. 2-6中のデターに付記したアルファベットは, Fig. 7-10 の筋電図記録に対応する試技の分析結果であ る.

両者の間には，全被験者でみると $\mathrm{r}=.952$ $(\mathrm{p}<.001)$ の高い相関と $\mathrm{y}=0.024 \mathrm{x}-6.56$ の回 㷌式が得られ，ボール速度の増大に上肢を速く 回すことの重要であることが認められた。 Zollinger $^{14)}$ 局関節で発揮されるトルクが ボール速度を決定する要因であることを報告し ている．熟練者，未熟練者に分けてみると，前 者では $\mathrm{y}=0.020 \mathrm{x}-1.28(\mathrm{r}=.913, \mathrm{p}<.001)$ ， 後者では $\mathrm{y}=0.015 \mathrm{x}+0.73(\mathrm{r}=.867, \mathrm{p}<.01)$ の回㷌直線が得られ, 回㷌係数, 相関係数之も に熟練者群が高値を示した。すなわち，熟練者 の方が上肢の回転によって得られた運動エネル ギーをより確実に，かつ効率よくボール速度に 結び付けていることが認められた。

Fig. 3 は，ボールの初速度 (y) と肩を中心と した上腕の角速度 $\left(\dot{\theta}_{1}\right)$ の最大値 $(\mathbf{x})$ (Fig. 7 参 照）の関係を，Fig. 4 は，手首の水平最大速度

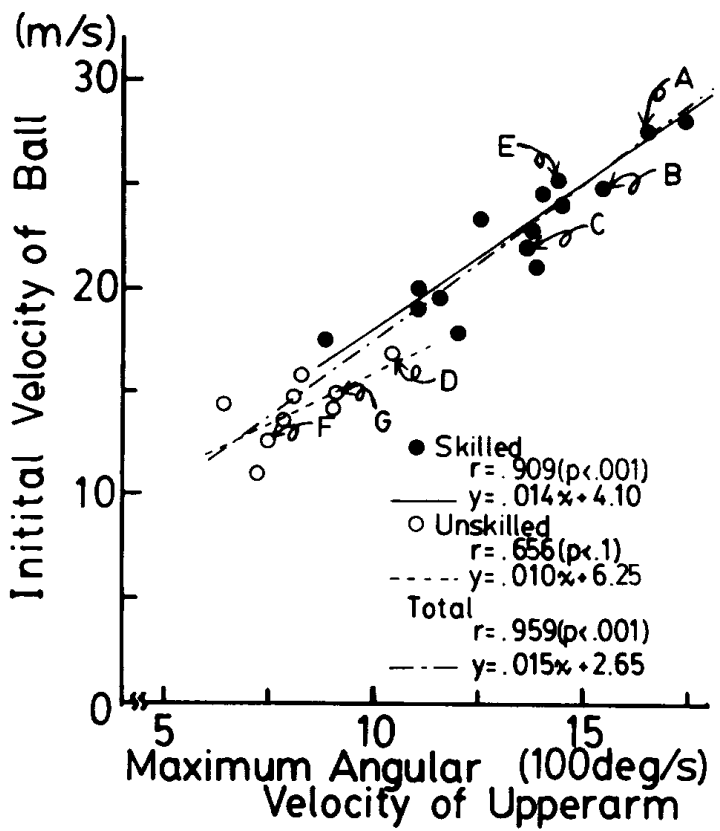

Fig. 3. The relationship between the initial velocity of ball $(y)$ and maximum angular velocity of upperarm about the shoulder joint $(\mathbf{x})$. 


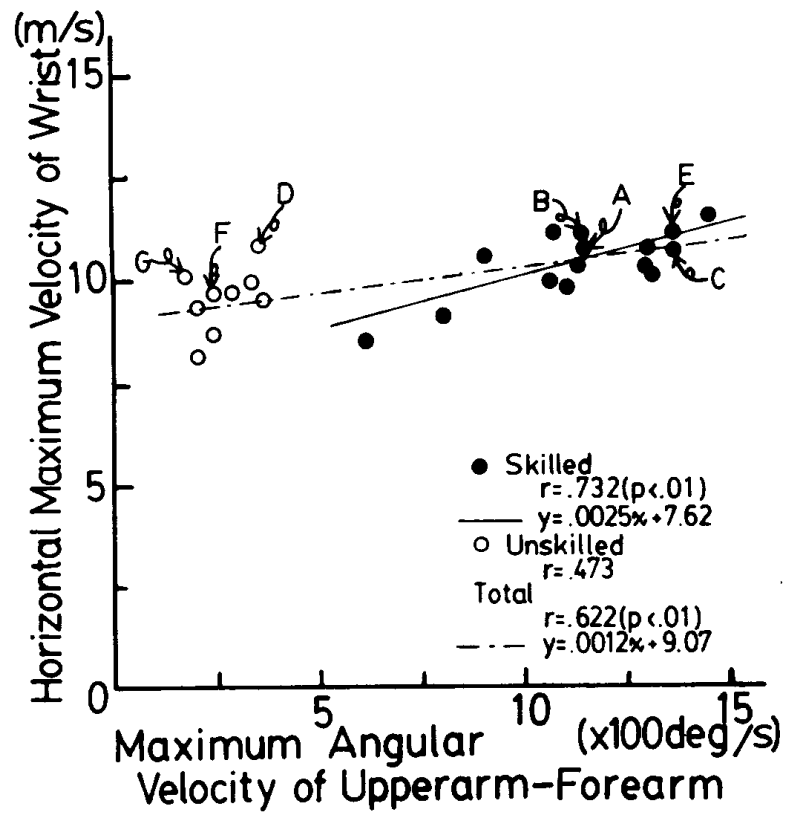

Fig. 4. The relationship between the horizontal maximum velocity of wrist $(y)$ and maxi. mum angular velocity of elbow ( $\mathbf{x}$ ) (between the upperarm and forearm.).

(y) と上腕に対する前腕の角速度 $\left(\dot{\theta}_{3}\right)$ の最大値 （x）（Fig. 7 参照）の関係を示している.

全被験者でみると，ボールの初速度と肩を中 心とした上腕の角速度の最大値の間には $\mathrm{r}=.959(\mathrm{p}<.001)$ の相関か，手首の水平最大 速度と上腕に対する前腕の角速度の最大値の間 には $\mathrm{r}=.622(\mathrm{p}<.01)$ の相関が得られた。すな わち，広い技能レベルを対象としてみた場合， 肩関節の回転の速さはボール速度の増大に強く 関係し，また，时関節の運動も手首の速度の増 大に関与することが示唆された。しかし，末熟 練者では，手首の水平最大速度と上腕に対する 前腕の角速度の最大値の間には，有意な相関関 係は認められなかった。これらのことから，前 述の局を中心とした上肢の角速度 $\left(\dot{\theta}_{2}\right)$ の最大值 とボール速度の対応関係が未熟練者で熟練者よ りも低かったことには，末熟練者では时関節の 運動が手首の速度の増大に利用されていないこ とが 1つの要因と考えられる。

Fig. 5 は，ボールの初速度 $(\mathrm{y})$ と手首の水平 最大速度 $(\mathrm{x})$ の関係を，Fig. 6 は，ボールの初 速度（y）とスナップ比（x) の関係を示してい

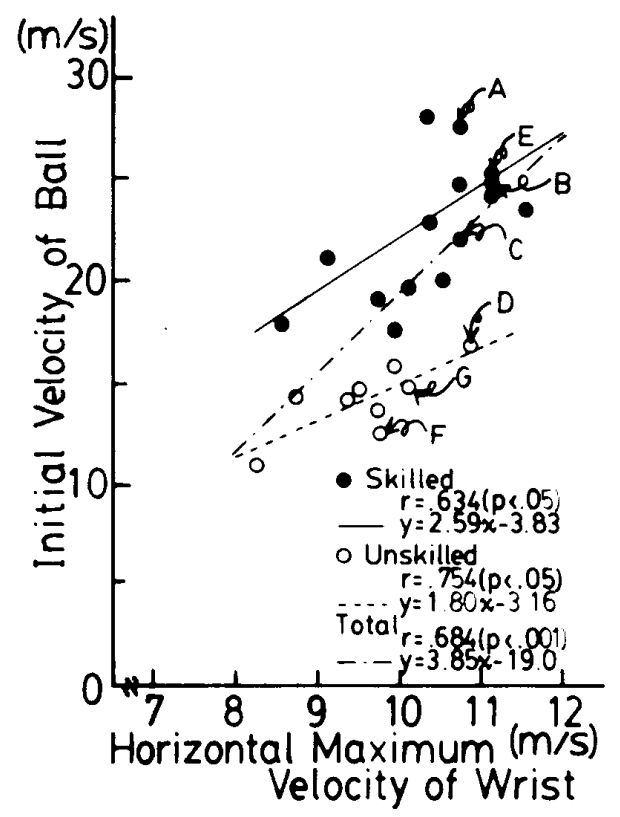

Fig. 5. The relationship between the initial velocity of ball $(y)$ and horizontal maximum velocity of wrist $(\mathbf{x})$.

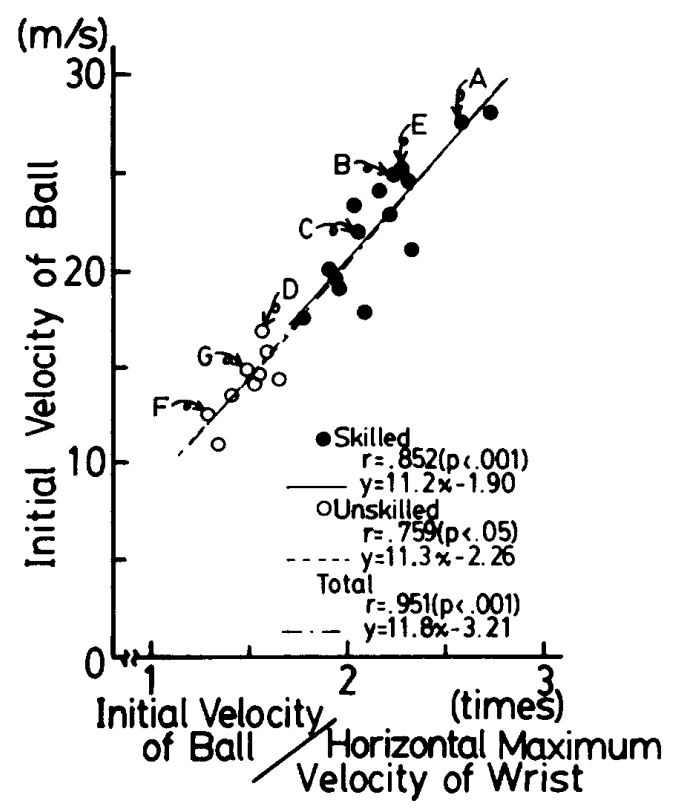

Fig. 6. The relationship between the initial velocity of ball $(y)$ and snap ratio $(x)$.

る。

熟練者，未熟練者を合わせてみると，ボール の初速度と手首の水平最大速度の間には $\mathrm{r}=.684(\mathrm{p}<.001)$, ボールの初速度とスナップ 比の間には $\mathrm{r}=.951(\mathrm{p}<.001)$ の相関が得られ た。すなわち，手首の速度を大きくすること， 
K.o.

(A)

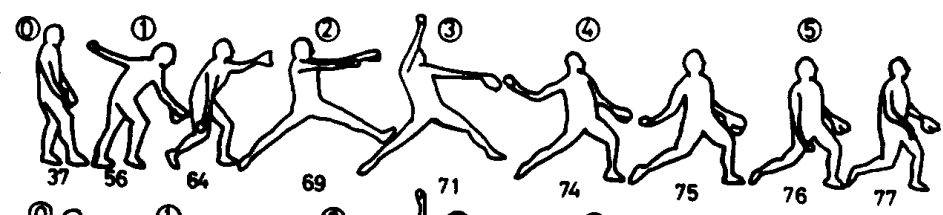

A. T.

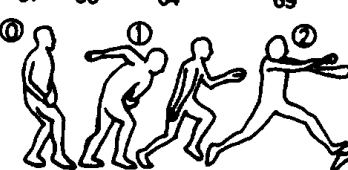

(B)

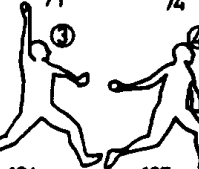

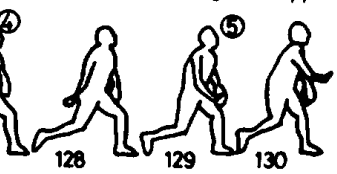

U.S.

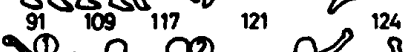

(C)
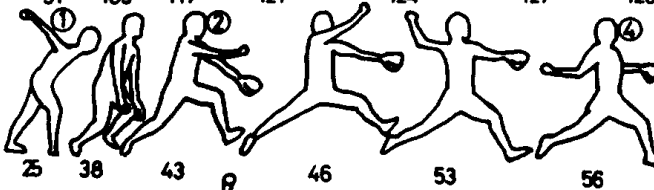

O.H.

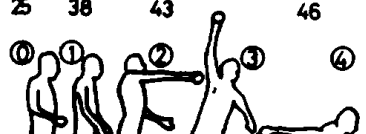

(D)
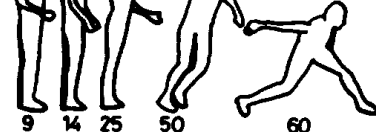

60

K.O.(skilled)

A.T.(skilled)

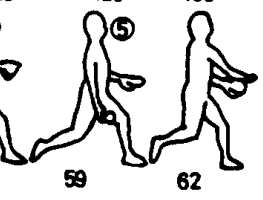
$24.8 \mathrm{~m} / \mathrm{s}$

62
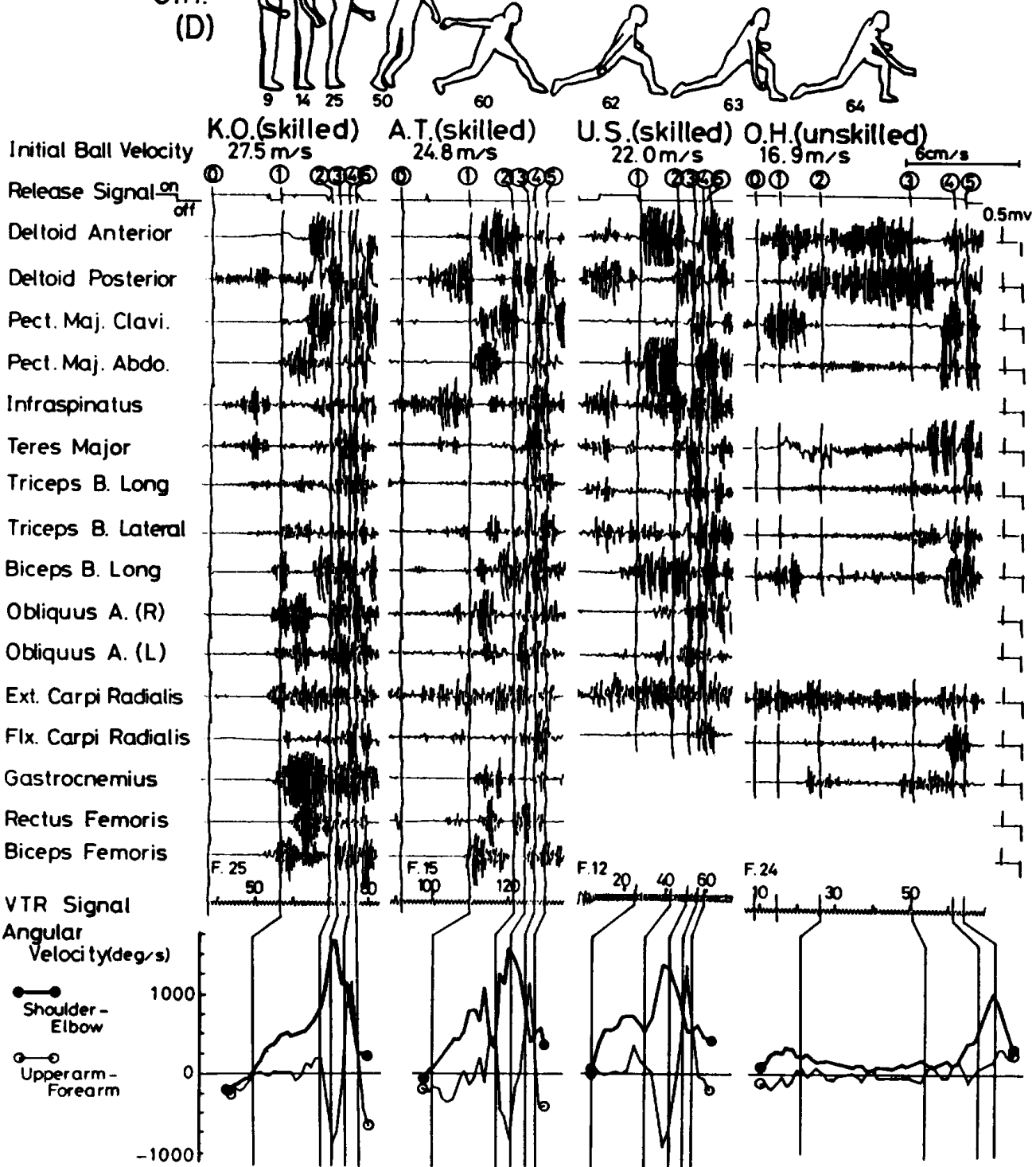

Fig. 7. EMG, form, and angular velocity of the shoulder joint $\left(\dot{\theta}_{1}\right)$ and of the elbow joint $\left(\dot{\theta}_{3}\right)$, during windmill pitch in various skilled level subjects.

The numbers (0) to (5) in EMG are the same as in form. Each number shows the point, (1): set up, (1): on set of the upperlimb move forward, (2): upperlimb through horizontal line in front of the body, (3): upperlimb through vertical line above the shoulder, (4): upperlimb through horizontal line at the back of the body, (5): position of releasing the softball.

The numbers under form are corresponding with VTR Signal. 
ならびにスナップ動作はボール速度を得るため に重要な要因であることが認められた。

ボールの初速度と手首の水平最大速度の関俰 を技術段階で比較すると，相関係数は熟練者の 方が低値を示したが，回㷌直線の傾きは熟練者 は 2.59 で, 未熟練者の 1.80 より高値を示した。 しかし, ボールの初速度とスナップ比の関係に おいては，熟練者と末熟練者の回帰直線は殆ど 一致することから，ボールの初速度と手首の水 平最大速度の間の回㷌俰数が熟練者で大きかっ た要因には，スナップ動作の習熟度が関係して いると考えられた。

\section{2. 助作パターンについて}

（1）競技レベルによりボール速度に差がみら れた要因

(a) 熟綀者について

Fig. 7 は，1 部リークの投手 K.O., 2 部リー グの投手の中で最も高いボール速度を示した A.T., 最も低いボール速度を示した U.S.,なら びに未熟練者 O.H. のウインドミル投法の筋電 㘡とフォーム，ならびに肩を中心とした上腕の 角速度，上腕に対する前腕の角速度の経時的变 化を示したすのである。なお，それぞれのデー ターはFig. 2-6中の A-D の試技におけるも のである。

因中の綎線(0はセットフップを，(1)は肩と ボールを結ぶ線が前方への運動を開始した時点 を，(2)は上肢が水平前方を，(3)は鉛直上方を， (4)は水平後方をそれそれれ通過した時点を，さら に(5)はリリース時を示している. 本研究では, (0)-(1)をティクバック期, (1)一(2)をフップワー ド期, (2)-(3)をバックワード前期, (3)-(4)をバッ クワード後期，(4)一(5)をフォワード期，(5)以降 をフォロースルー期と呼ぶことにした。

最も高いボール速度を示したK.O. について みると,テイクバック期（(0)一(1)）三角筋後部 に持続放龟がみられ, 棘下筋, 大円筋にも少し 遅れて放龟が認められた。 また，上腕三頭筋長 頭，同外側頭にも弱い持続放電がみられた。こ れらのことから, 打者にボールの握りを隠すよ 5に上腕を内旋しながら肘网節を伸展し，局関
節を内転ぎみに伸展することによってテイク バックしていると考えられた。

フップワード期（1)一(2)）では，上腕三頭筋 長頭, 同外側頭に弱い持続放龟がみられ，(1)の 直後には上腕二頭筋にバーストがみられた。さ らに，この期の前半には三角筋後部，大胸筋腹 部, 後半には三角筋前部, 大胸筋銷骨部, 上腕 二頭筋に放龟が認められた。この間，时関節は 伸展されていることから，上腕二頭筋の放電は 肩関節の屈曲に働いていると考えられる. アップワード期前半には三角筋前部に放電のみ られないことから，时関節伸展位で肩関節を内 転ぎみに屈曲しているが，肩関節の屈曲は主と して重力の利用によって行われていると考えら れる。

下肢筋では，腓腹筋に強い持続放電がみられ， 前半は大派二頭筋, 後半は股関節外転の分力を 持つ大腿直筋 ${ }^{2} に$ 放電が認められた。すなわち, アップワード期（1)-(2)）前半は股関節の伸展 と足底屈によって，後半は股関節の外転，㮏闺 節の伸展, ならびに足底屈によって後方にキッ クしていると考えられた，本被験者のステップ 幅は，身長の $105 \%$ ，野球投手のオーバー八 ンドスロー(約 $70 \%)^{5)}$ より高値であった。

ハッックワード前期（(2)-(3)）には，肩関節筋 では三角筋後部にのみ放電がみられ，肩関節は 外転ぎみに屈曲されていることが分かる。

したがって，(3)直後に最大值を示す肩を中心 とした上腕の角速度は, 肩関節の外転ぎみの屈 曲とステップによる身体の前方への並進運動に よりもたらされているものと考えられる。

ハックワード後期（(3)-(4)）には，三角筋後 部，大円筋に放龟がみられ，肩関節は身体後方 に力を加えながら ${ }^{8}$ 前額面での内転と上腕の外 旋を行っていると考えられた。

また，バックワード後期（3)-(4)）にみられ る上腕二頭筋の放電は, 肘関節の屈曲・回外に 值き手掌を上方に向けていた。

フォワード期 (4)一(5)）においては，大円筋, 三角筋後部に放電はみられるが三角筋前部には 放電のみられないことから，局関節は前額面で 
身体後方に力を加えながら内転到を行っている と考えられた。このよ5に, 局関節の内転でフォ ワードスイングを行らことは，肩関節の屈曲よ りも大きな力を発揮でき，高いボール速度を獾 得するための合目的的な動作であると考えられ る.

また, リリース直前には上腕二頭筋の放電が 消失し，これに呼応して上腕三頭筋長頭に放電 がみられ，屈曲・回外位にあった肘関節を伸展・ 回内しながらボールを投射していることが分か る.

肩を中心とした上腕の角速度は，バックワー ド後期（3)-(4)）からフォワード期 (4)-(5) に急做に低減し，逆に，上腕に対寸る前腕の角 速度の急増が認められた。このことは，質量が 大きく回転の中心に近い部位の速度を急激に低 下させることによって末端の速度を増大させて いることを意味している，すなわち，上腕から 前脆へのエネルギーの転移が示唆され，前述し た熟練者で时関節が有効に利用されていること

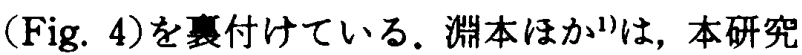
のフォワード期に相当する局面の映像分析から 上腕から前腕へのエネルギー転移の可能性は少 ないとしているが，投手と野手のボール速度の 差は肘関節の動きとスナップ動作にあることを 報告している.これらのことを考え合わせると， 上腕から前腕へのエネルギーの転移はバック ワード後期からフォワードスイングの前半に行 われており时関節の伸展を有効に利用すること が高いボール速度を得るための 1 つの要因であ ると考えられる。

暁側手根屈笳はフォワード期（4)-(5)）に顕 著な放電を示すのに対し，拮抗矨の暁側手根伸 筋の放龟が消失し，スナップ動作の合理的に行 われていることが認められた。事実，本試技の スナップ比は $2.57 て ゙$ 他の被験者よりる高値を 示した。

さらに，右の外腹斜筋に放電がみられ躯幹を 投方向へ捻り戻していることが認められた。

次に， 2 部リークの投手 A.T.についてみる と，フップロード期（1)-(2)）の前半, 三角筋
後部に放電はみられず，三角筋前部の放電が早 期に出現する傾向がみられた。ささらに，フップ ワード期後半, 三角筋前部の放電の弱くなる傾 向がみられた。一方，肩を中心とした上腕の角 速度は，K.O.に比して早期に増大寸るが，アッ プワード期後半に一時低下がみられ，バック ワード前期に再び上昇するパターンを示し， 2 段モーションで上肢を回転させていることが認 められた。すなわち，上肢の回転の途切れが， 肩を中心とした上腕の角速度の最大值を K.O. に比して小さくした要因と考えられる。

また，フォワード期（(4)-(5)）においても， 三角筋後部，大円筋の放奄が弱く，逆に大胸筋 腹部，碀下筋の放龟が顕著にみられた。このこ とは，A.T.では身体前方に力を加えながら内 転8)していることを示し，K.O. と異なり，前腕 上部を躯幹に積極的に当てていないものと考え られる，前腕上部を躯幹に強く当てることは， K.O. の手首の水平最大速度は $10.7 \mathrm{~m} / \mathrm{s}$ でボー

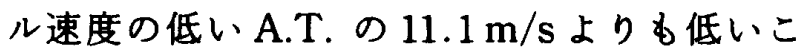
とから, 手首の速度増大よりも前腕の運動エネ ルギーの手・ボールへの転移に関釈しているも のと推察される。

さらに，暁側手根伸筋の放電がフォワード期 にも残存する㑯向がみられた。

これらのことがA.T.のスナップ比 (2.23)を K.O.（2.57）に比して小さくした要因と考えら

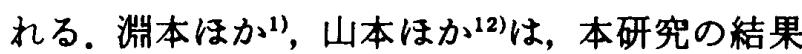
と同様に，熟練者においてはリリース直前に手 関節伸筋から屈筋への放龟の切り換わりがみら れるのに対し，末熟練者では手関節伸筋の放龟 が残存することを認めている.また, Zollinger ${ }^{14)}$ は周関節と手闺節の回転要素によってボール速 度が決定されるとしている。これらのことから， スナップ技術はボール速度を決定する重要な要 因と考光られる。

A.T.の身体重心の水平最大速度は $2.9 \mathrm{~m} / \mathrm{s}$, ステップ幅の身長比は $100 \%$ \%で，いずれる.O. （それぞれ $3.0 \mathrm{~m} / \mathrm{s} ， 105 \%$ ）よりも低值を示し た。これには，腓腹筋や大䃘直筋の放龟量から 推定されるように後方へのキックの弱いことが 

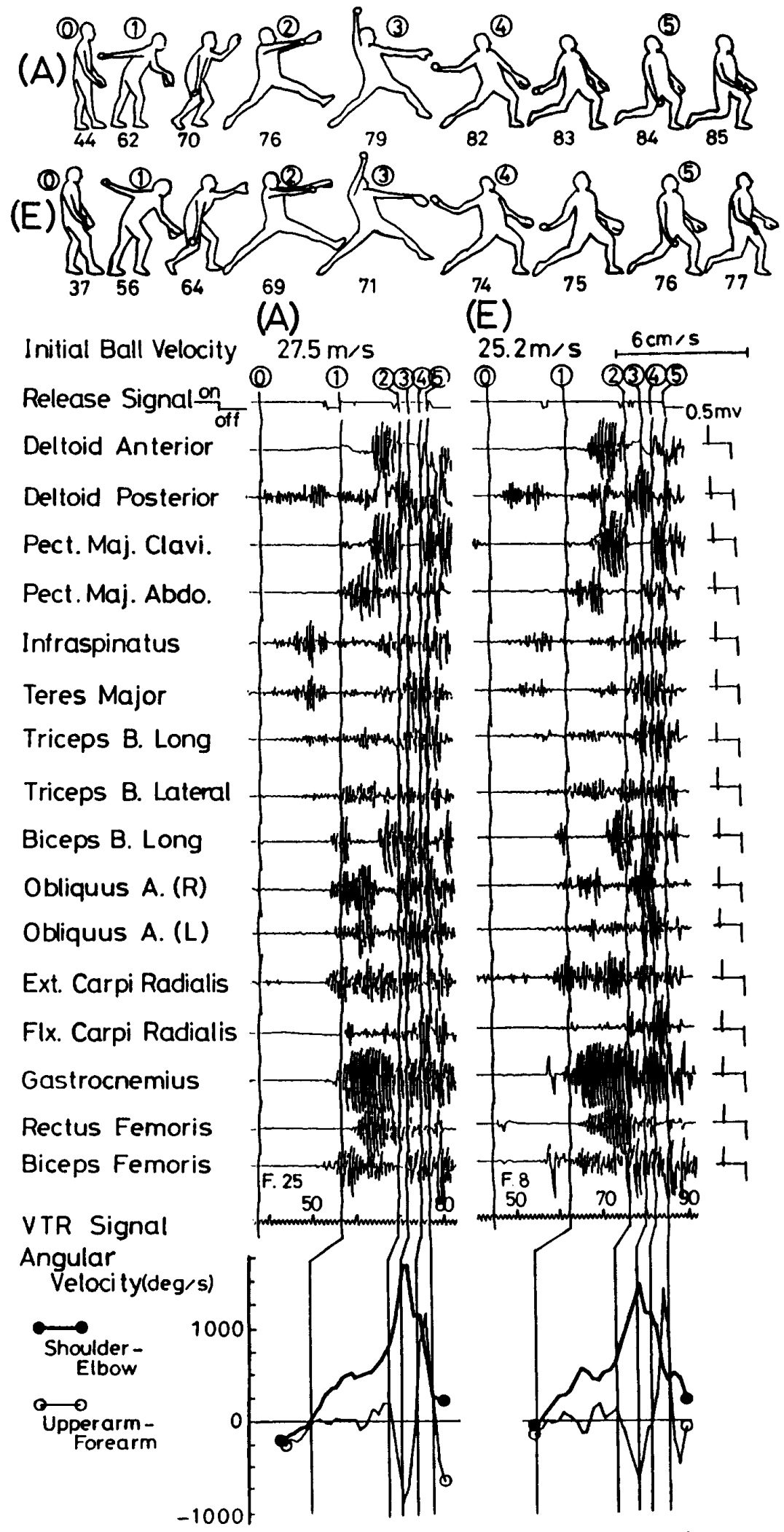

Fig. 8. EMG, form, and angular velocity of the shoulder joint $\left(\dot{\theta}_{1}\right)$ and of the elbow joint $\left(\dot{\theta}_{3}\right)$ in subject K.O. (skilled) at different ball velocity.

The numbers under form are corresponding with VTR Signal. (The numbers (0) to (5) in this figure are the same as in Fig. 7.) 


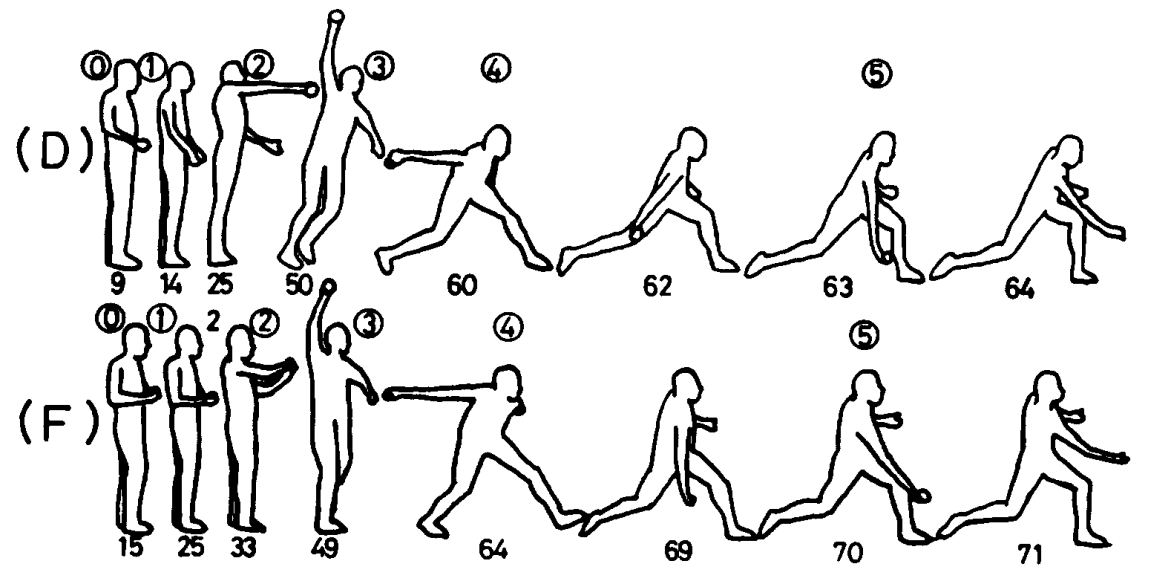

(D)

(F)

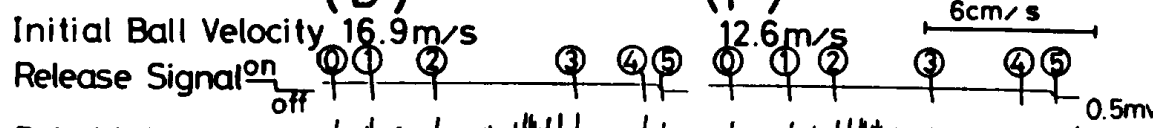

Deltoid Anterior

Deltoid Posterior

Pect. Maj. Clavi.

Pect. Maj. Abdo.

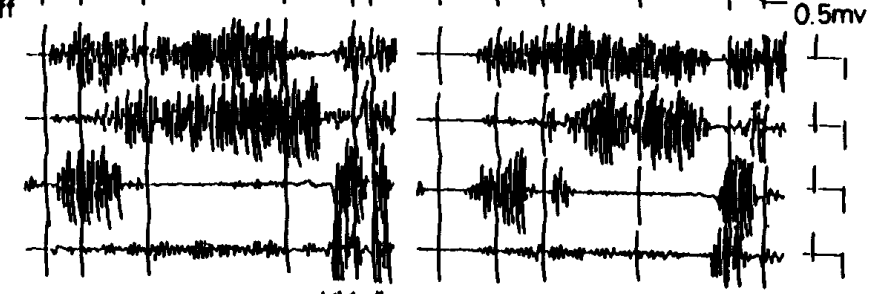

Teres Major

Triceps B. Long

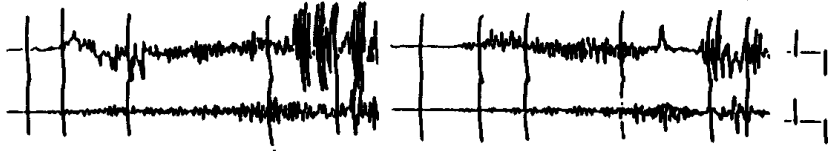

Triceps B. Lateral

Biceps B. Long

Ext. Carpi Radialis

Flx. Carpi Radialis

Gastrocnemius

VTR Signal

Angular

Velocity

(deg/s)
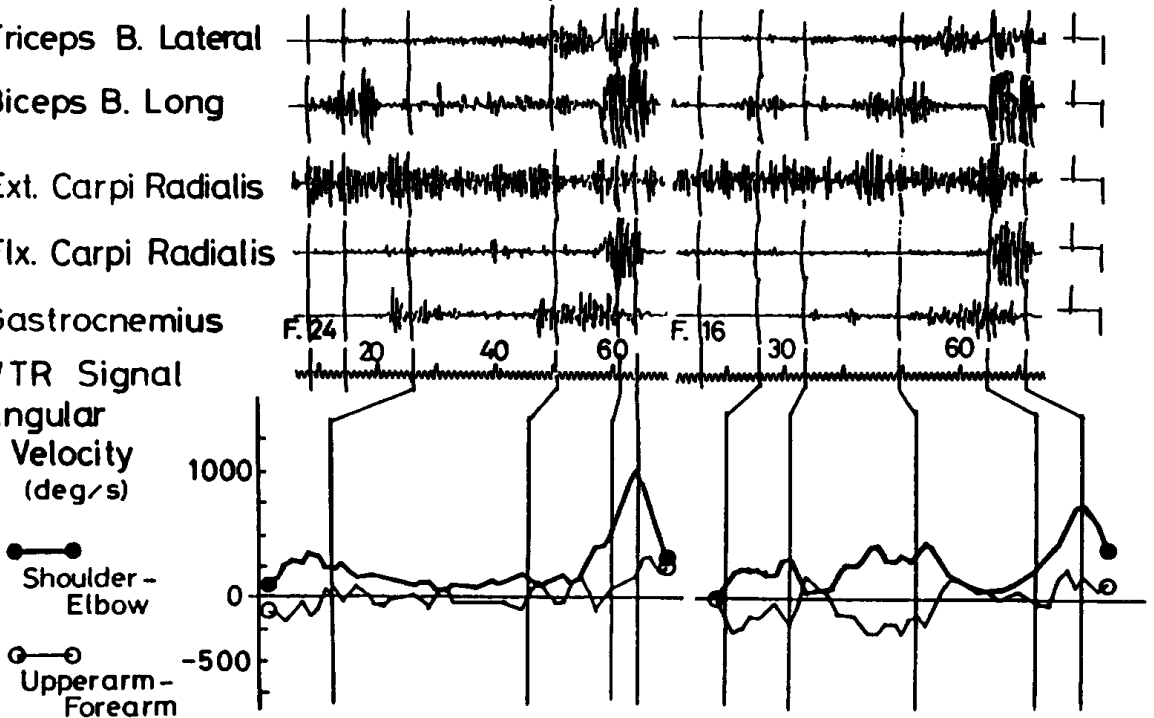

Fig. 9. EMG, form, and angular velocity of the shoulder joint $\left(\dot{\theta}_{1}\right)$ and of the elbow joint $\left(\dot{\theta}_{3}\right)$ in subject $\mathrm{O}$.H. (unskilled) at different ball velocity.

The numbers under form are corresponding with VTR Signal. (The numbers (0) to (5) in this figure are the same as in Fig. 7.)

関係し，キックカもボール速度に関与する要因 と考えられる。

熟練者の中で最もボール速度の低かったU． S. では，アップワード期（1)一(2)）前半の三角
筋前部の放龟が A.T. よりもさらに早期に出現 する傾向が認められた。

また，フォワード期（(4)一(5)）の橈側手根伸 筋の放電が，A.T. と同様に，わずかに残存し， 
スナップ比も 2.05 であることからも分かるよ らに，スナップ動作が合理的に行われていな かった。

以上 3 名の熟練者にみられたボール速度に差 をもたらした要因は，他の熟練者においてもは ぼ同様に認められた。

すなわち，フップワード期における肩を中心 とした上腕の角速度の増大のタイミングを遅ら せ上腕の回転に途切れを生じさせずに大きな角 速度を得ること，リリース直前に前腕上部を躯 幹に強く当て前腕の運動エネルギーを手・ボー ルに転移すること、リリース直前に手関節伸筋 の放龟を抑制し手関節の屈曲を合理的に行うこ と, 後方へのキックを強力に行うこと等がボー ル速度の增大に関与する要因と考兄られた。

（b）未熟練者について

未熟練者 O.H. では，熟練者にみられたテイ クハッック動作はみられず，七ットアッブから直 接アップワード動作を行っていた。

アップワード期（1)一(2)）前半には，大胸筋 鎖骨部，三角筋前部，上腕二頭筋に放電がみら れ，肩関節を内転ぎみに屈曲していることが認 められた。しかし，熟練者と異なりフップワー ド期後半にはこれらの筋の放奄は减少・消失し， 三角筋後部に放電がみられた。この間，大胸筋 腹部には殆ど放電の認められないことから，末 熟練者は有関節を外転ぎみに屈曲しているもの と考えられる。

ハックワード前期（2(2)-(3)）には，三角筋前 部，同後部に放電がみられ，局成節を外転ぎみ に屈曲していた，さらに，シックワード後期(3) 一(4)）では，三角筋後部の放電消失後，大胸筋 鎖骨部，同腹部，大円筋に放電が認められ，肩 関節は外転ぎみの屈曲から内転しているものと 考えられた。

また，上腕三頭筋長頭，同外側頭に放龟がみ られ，上腕二頭筋に放電のみられないことから， 手掌を下方に向け时阙節をバックスインクの間 伸展位に保持していることが認められた。すな わち，末熟練者ではフォワードスイングで时関 節の伸展を利用できなかったことが，前述の上
腕に対する前腕の角速度の最大值と手首の水平 最大速度の間（Fig. 4）に有意な相関を示さな かった要因と考えられる。

フォワード期（4)-(5)）には，大胸筋腹部の 放電に休止が認められ，その間，三角筋前部， 同後部の順に放電がみられた。 また，上腕二頭 筋にも放電がみられたが，时関節に屈曲のみら れないことから，局関節の屈曲に働いているす のと考えられる.

すなわち，末熟練者では，熟綀者と異なり， 屃関節の外転ぎみの屈曲によってボールを投射 していることが認められた。

さらに，本被験者のステップ幅は身長の $85 \%$, 身体重心の水平最大速度は $2.4 \mathrm{~m} / \mathrm{s}$ で, 熟練者よりす低值を示した。

以上の未熟練者と熟練者の動作パターンの相 違から，肩関節の内転・内旋と时関節の伸展 回内により投射すること，ステップによって躯 幹の並進運動量を大きくすること等がボール速 度の増大に関与する要因と考えられた。

（2）ボール速度を变えて投げた场合の筋放軍

\section{菉相の变化}

Fig. 8 は，K.O. が異なる速度〔左側（A）： $27.5 \mathrm{~m} / \mathrm{s}$, 右側 $(\mathrm{E}): 25.2 \mathrm{~m} / \mathrm{s}$ ] でボールを投 げた際の筋電困を示したものである。

ハッックード前期（2)-(3)）の三角筋後部の 放電は，ボール速度の高い(A)の場合に顕著に 認められた（3直後にみられる肩を中心とした 上腕の角速度の最大值は，(A) の方が（E）よ り亮值 $(\mathrm{A}: 1,651 \mathrm{deg} / \mathrm{s}, \mathrm{E}: 1,435 \mathrm{deg} / \mathrm{s})$ を示し, 三角筋後部の放龟は上腕の回転速度に 関係していると推定された。

また，フォワード期（4)-(5)）では，(A)の 場合棘下筋の放電が弱く大円筋の放電がリリー ス直前に顕著になる傾向が認められ，(E)に比 ベ身体後方への力の加方方が強く, 前腕上部の 躯幹への当て方が積極的であることを示した。 このことは，(A)の場合上腕に対する前腕の角 速度の最大値 $(1,144 \mathrm{deg} / \mathrm{s})$ p手首の水平最大 速度 $(10.7 \mathrm{~m} / \mathrm{s})$; , (E) $(1,362 \mathrm{deg} / \mathrm{s}, 11.1$ $\mathrm{m} / \mathrm{s})$ よりす低いにもかかわらず, スナッブ比を 
(D)

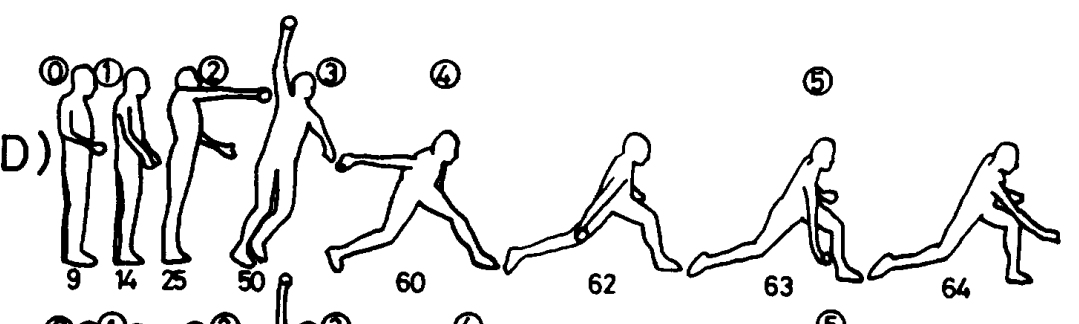

(G)

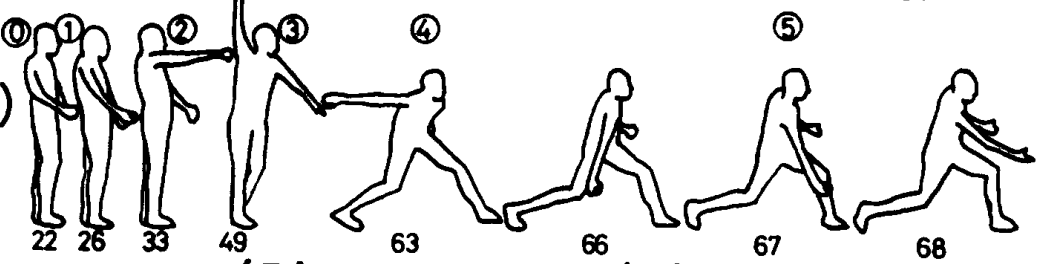

(D)

(G)
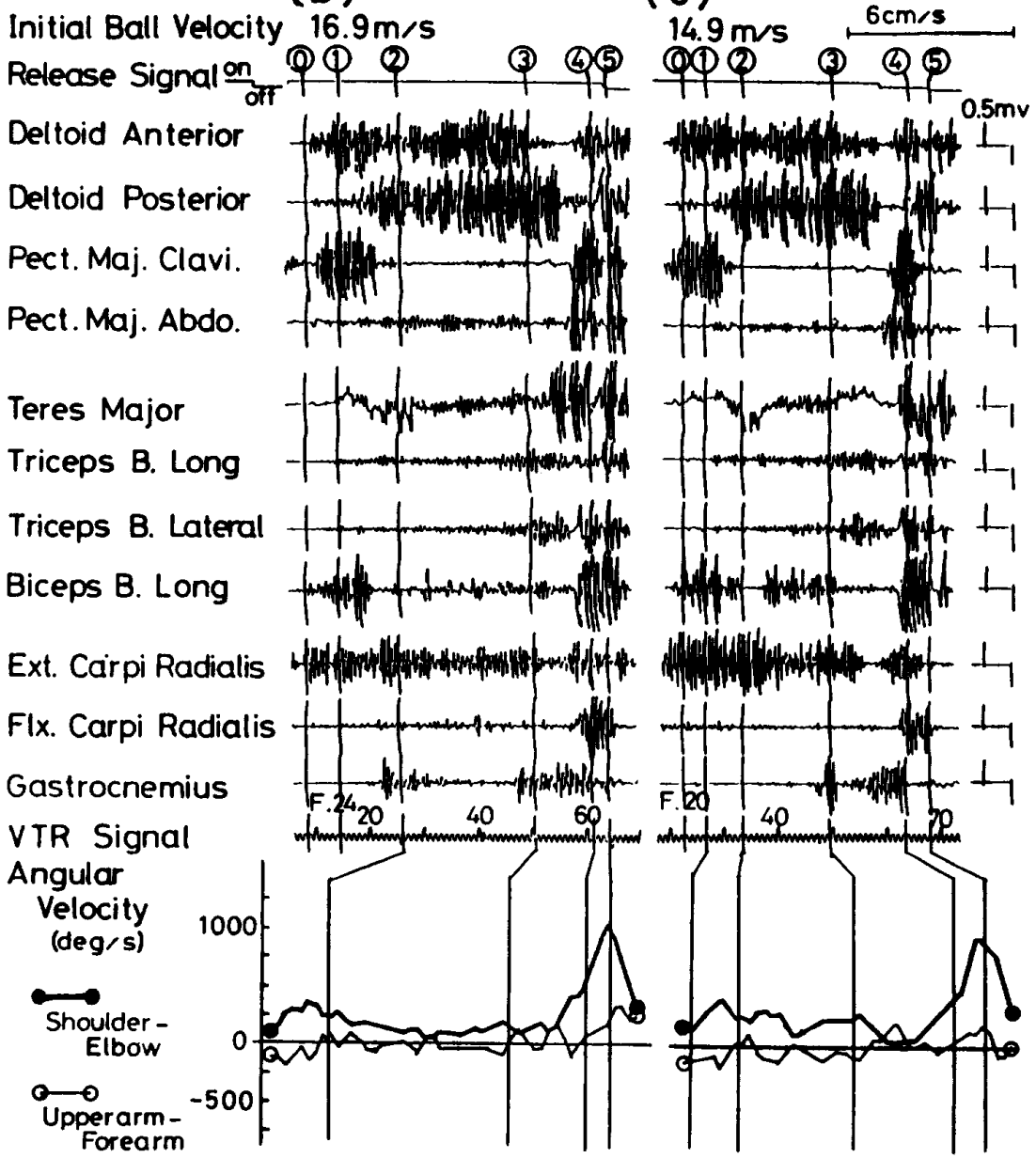

Fig. 10. EMG, form, and angular velocity of the shoulder joint $\left(\dot{\theta}_{1}\right)$ and of the elbow joint $\left(\dot{\theta}_{3}\right)$ in subject $\mathrm{O} . \mathrm{H}$. (unskilled) which shows differnt ball velocity though he pitches in maximum effort.

The numbers under form are corresponding with VTR Signal. (The numbers (0) to (5) in this figure are the same as in Fig. 7.)

(E) よりも高くした $(\mathrm{A}: 2.57, \mathrm{E}: 2.27)$ 要因 の 1 つ考えられる。

さらに，フォワード期（4)-(5)）に括ける外 腹斜筋右側の放電も(A)の方が顕著である傾向
がみられ，躯幹の念りの強さもボール速度の増 大に貢献していると考えられた。

以上のことから，上肢の回転速度，躯幹に前 腕上部を当てる強さ，ならびに躯幹の捻りの程 
度によって，熟練者はボール速度を調節してい ると考えられた。

Fig. 9 は，未熟練者 O.H. が異なる速度〔左側 (D) $: 16.9 \mathrm{~m} / \mathrm{s}$, 右側 (F) $: 12.6 \mathrm{~m} / \mathrm{s}]$ でボー ルを投げた際の筋電困を示したすのである。

ボール速度の低い（F）の試技においては， ハッッワード後期（(3)-(4)）からフォワード期 (4)-(5))前半にかけての大胸筋腹部, 同鎖骨部, 大円筋の放奄の出現が (D) の場合よりも遅れ, 上肢に力を加えるタイミングに相違がみられ た.このことは，眉を中心とした上腕の角速度 の経時的変化からす認められる.すなわち, 上 腕の回転速度を高めるタイミングを変化させ, ボールに力を加える作用距離を变えることに よって，上肢の角速度を調整しボール速度を調 節していると考えられた。

また，ハックワード後期の腓腹筋の放電は （F）の試技において弱く，後方へのキックの弱 いことが認められた。事実, (F) の場合, 身体 重心の水平最大速度は $2.1 \mathrm{~m} / \mathrm{s}$, ステップ幅は 身長の $75 \%$ ，（D）のそれ $(2.4 \mathrm{~m} / \mathrm{s} ， 85 \%)$ よりも小さかった。これらのことから，本被験 者ではキック力によってもボール速度を調節し ていると考えられた。

以上の結果, 未熟練者ではステップの大きさ や上肢の回転速度を高めるタイミングといった 打者から比較的分かりやすい方法でボール速度 の調節を行っているのに対し，熟練者は動作全 体を通しての上腕の回転速度，躯幹に前腕上部 を当てる強さ，躯幹の捻りの強さといった打者 から察知しにくい方法で行っていることが認め られた。

（3）全力で投げたにもかかわらずボール速度 に差のみられた票因

熟練者では，全力で投げた場合のボール速度 の差は最大 $0.9 \mathrm{~m} / \mathrm{s}$ (最大ボール速度の $3.8 \%$ ) で，比較的安定してパフォーマンスを発揮して いた。しかし，末熟練者では全力で同じょうに 投げたにるかかわらずボール速度に著しい相違 のみられる試技が認められたのでその要因を検 討した。
Fig. 10 は，前述の未熟練者 O.H. が全力で投 球したにもかかわらずボール速度にかなりの差 がみられた試技〔左側 (D) $: 16.9 \mathrm{~m} / \mathrm{s}$, 右側 (G) $: 14.9 \mathrm{~m} / \mathrm{s}$ ]の筋電図を示したものである. バックワード後期(3)—(4)), 眉関節の内転に 働く大胸筋鎖骨部, 同腹部の放電がボール速度 の低い（G）の場合の方が (D)よりも弱く, 主 放電の出現がフォワード期（(4)一-(5)）にみられ る傾向が認められた。すなわち，上肢に力を加 えるタイミングが遅れ，これが $(\mathrm{G})$ での眉を中 心とした上腕の角速度の最大値を小さくした要 因と考えられる。

また, リリース時の肩峰突起と尺骨茎状突起 を結ぶ線が鉛直線の前方でなす角度は，(D) で は 5.3 度，(G)では 17.8 度を示し,リリース位 置の一定しない傾向がみられた（G）のように リリース位置が前になった場合，リリース直後 に大胸筋鎖骨部が積極的に働けば，眉関節を内 転ぎみに屈曲しボールを上方に投げ上げてしま らことになるので放龟がみられなかったるのと 考えられる。

さらに，フォワード期の橈側手根屈筋の放電 は (G)の場合に弱く，逆に暁側手根伸筋の放龟 が残存する傾向を示した。

すなわち，(D) のよ5にバックワード後期か ら上腕の角速度を高めるとともに，リリースを 鉛直線に近い位置で行い指にボールがかかった スナップ動作が行えれば，比較的高いボール速 度の得られることが認められた。 また，当然で はあるがリリース位圈を一定にすることは正確 性の向上にるつながるるのと考えられる。

以上の技術段階やボール速度の異なる投球の 比較検討から，ボール速度の增大に関与する要 因として以下の 7 点が考えられた。

すなわち，(i）軸脚の後方へのキックを強く 行い, 大きなステップ動作により身体重心の並 進速度を高めること.（ii）上肢の回転速度を高 めること。（iii）躯幹を投方向に対して横に向 け，フォワードスイングを肩関節の屈曲ではな く内転で行い大きな力を発揮できるよ5にする こと.（iv）フォワードスイングに協応して躯幹 
を投方向に向け，躯幹の捻りを利用すること． （v）フォワードスインクに肘関節の伸展・回内 を利用すること.（vi）前腕上部を躯幹に強く当 て，前腕の運動エネルギーを手・ボールに転移 すること.（vii）リリース位置を安定させ，リ リース直前に手䦳伸筋の放奄を抑制すること により合理的にスナッブ動作を行らこと，であ る.

これらの技術要因の重要度や指普法（順序・ 方法）については，今後さらに検討する必要が ある.

\section{IV. 要 約}

技術段階の異なる被匼者 8 名を対象にウイン ドミル投法により種々の速度のボールを投げさ せ，その際の動作をビデオカメラと筋䉓図を用 いて記録し，技術段階とボール速度による相違 を検討した。

1.ボールの初速度（y）と局と手首を結んた 線の局関節を中心とした角速度の最大值 $(\mathbf{x}) の$ 間には，效練者ではy $=0.020 \mathrm{x}-1.28$ $(r=.913, p<.001)$ ，末热娻者では $y=0.015 x+0.73$ $(r=.867, p<.01)$ の䍏係が得られた。

2. 未热練者では, 手首の水平取大速度と上腕 に対する前腕の角速度の最大值の間には有意な 相威は得られず，肘関節の伸展が投球に利用さ れていないと考えられた。

3. ボールの初速度 $(\mathrm{y})$ とリリース直前の手 首の水平最大速度 $(\mathbf{x})$ の間には，熟練者 $(\mathrm{r}=.634, \mathrm{p}<.05)$ ，未熟練者 $(\mathrm{r}=.754, \mathrm{p}<.05)$ のいずれにおいてす有意な相関關が認められ たか，回㛿係数は熟練者の方が高值を示した。

4. ボールの初速度とスナップ比の間には, 热 練者 $(\mathrm{r}=.852, \mathrm{p}<.001)$ ，未熟練者 $(\mathrm{r}=.759$ ， $\mathrm{p}$ <.05）のいずれにおいて子有意な相開威係が 得られた。また，回㷌係数は，熟練者と末熟練 者で殆ど差はみられなかった。

5. 筋龟図の解析結果から，熟練者は，キック を稓極的に行い，躯幹を投方向に対して横に向 けながら上腕の回伝速度を高め，躯幹の捻りを 利用し，フォワードスイングを肩関節の内転・
内旋で行い，时閏節を伸展・回内することによ ク，ボールを投射していると考えられた。一方， 末熟練者では,キックが積極的に行われず, フォ ワードスイングを肩関節の外転ぎみの屈曲で行 い, 肘関節の伸展の利用されていないことが認 められた。

6. 熟練者においても競技レベルによって ボール速度に差異がみられ，上腕の回転速度の 大きさ，フォワード期に前腕上部を躯幹に当て ることによる前腕の運動エネルギーの手・ボー ルへの転移，スナップ動作における拮抗筋の放 龟の抑制，ならびに身体重心の並進速度の大き さ等の相違がその要因として考えられた。

7. ボール速度の調節は, 熟練者では上肢の回 転速度，躯幹に前腕上部を当てる強さ，躯幹の 捻りの強さといった打者が察知しにくい方法に よってなされているのに対し，未熟練者では後 方へのキックの強さ，上腕の回転速度を高める タイミングを変化することによって行っている と考えられた。

8. 未熟練者ではパフォーマンスを安定して 発撞できない傾向がみられ，上腕に力を加える タイミング，ボールのリリース位置に基因する スナップ動作の不安定さがその要因と考えられ た。

以上の結果，ボール速度を高めるための技術 ポイントとして，(i) 身体重心の並進速度を高 めること.（ii）上肢の回転速度を高めること． （iii）躯幹の捻りを利用すること。（iv）フォ ワードスイングを局関節の内転で行うこと。

（v）フォワードスイングで时関節の伸展を利 用すること.（vi）前腕上部を躯幹に強く当てる こと.（vii）スナップ動作時，拮抗筋の放奄を抑 制すること。（viii）リリース位置を安定させる こと等が考えられた。

\section{文献（References）}

1）渒本隆文・伊藤 童・金子公有（1984）ソフトボー ルゥインドミル投法における速度の決定要因. 星川 保・當盘進太郎編 走・跳・投・打・泳運動におけ る“よい動き”とは．第７回日本ハイオメカニクス 学会大会組織委員会：名古屋, pp. 119-122. 
2）後藤幸弘・熊本水頼・山下譜智・岡本 勉（1974）下 肢の基本動作における下肢筋群のき方について 一各種垂直面内における杽上一，体育学研究 18 : $269-276$.

3）後藤幸弘・風井訫㭟・岡本 勉（1979）ビッチャの投げの筋電図的分析. 体育の科学 $29: 533-538$.

4）平野裕一（1982）投げに関する文献紹介.J.J. Sports Sci. 1 : 110-113.

5）平野裕一・浅見俊雄（1988）野球の投球動作とその 指这. 体育の科学 $38: 93-100$.

6）風井訫巷・熊本水頼・岡本 勉・山下铎智・後藤幸 弘・丸山宣武（1976）野球の投動作（オーバーハン ドスロー）における上肢・上肢带筋群の作用機序。 体育学研究 $21: 137-144$.

7) Miller, R.G. and Shay, C.T. (1964) Relationship of reaction time the speed of a softball. Res. Quart. 35: 433-437.

8）岡本 勉・高木公三郎・管本水頼（1966）上肢の伸 展動作の筋電図学的研究. 体力科学 $15: 37-42$.

9) Okamoto, T. (1968) A study of the variation of discharge pattern during flexion of the upper extremity. 间西医科大学教菱部紀要 $2: 111-122$.

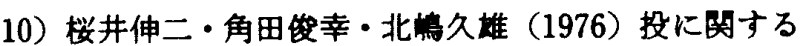
研究成果. 昭和 51 年度日本体䏍協会スポーツ科学 研究報告, No I 投能力の向上に闺する研究 : 12 -23 .

11）桜井伸二・宮下充正（1982）子どすにみられるオー パーハンド投げの発達. J. J. Sports Sci. 1：152 $-156$.

12）山本英弘・北川 蓝・松岡弘記・藤松 博（1981）ウ インドミル投法の功作分析的研究. 中京体育学研究 $21: 114-121$.

13）吉野みね子（1970）ソフトボールにおけるビッチ ンクの功作分析および筇奄図学的研究一ウインド ミル投法とスリングシッョト投法について一. 東京 女子体育大学紀要 5:115-118.

14) Zollinger, R.L. (1973) Mechanical analysis of windmill fast pitch in women's softball. Res. Quart. $44: 290-300$.

（平成 2 年 6 月 13 日受付） 